Copyright (C) 2015 by Academic Publishing House Researcher

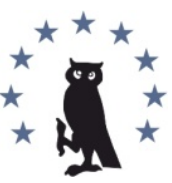

Published in the Russian Federation

European Researcher

Has been issued since 2010 .

ISSN 2219-8229

E-ISSN 2224-0136

Vol. 98, Is. 9, pp. 637-646, 2015

DOI: $10.13187 /$ er.2015.98.637

www.erjournal.ru

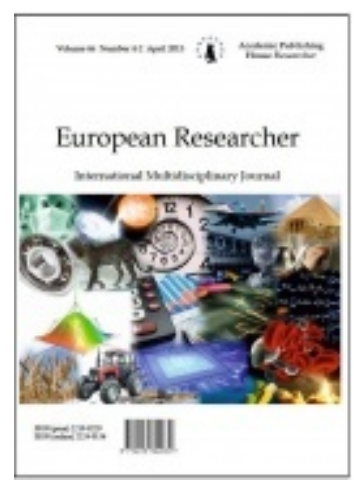

UDC 338.12

\title{
Current Development of Meat-Processing Industry in Ukraine: Tendencies, Problems and Strategies for Solution
}

\author{
Kateryna Vlasova
}

Taras Shevchenko Kyiv National University, Ukraine

PhD student

E-mail: nadtochii@ukr.net

\section{Abstract}

This article describes the current state of all meat-processing companies in Ukraine by using such indexes as the main measures for it: number of employees involved in this particular industry and whole processing industry, number of companies in an industry etc. An author suggests to study self-sufficiency of main products as a result of activity of meat-processing companies in domestic market and a dynamics of trade balance by different meat types as a result/ success on international market. The given analysis pay attention to main problems in the industry: negative trade balance, lack of production in strategic spheres, higher prices of imported goods compared to cheaper national product. A structure of export was compared to its import to identify most unbalanced categories in home market. An analysis of geographical structure of export/import operations showed a disproportion that can bring to constant negative transformation of meatprocessing industry. A number of strategies to overcome these problems is proposed.

Keywords: barriers to entry, meat-processing industry, investments, self-suffiency, trade balance, strategies to overcome problems.

\section{Introduction}

Industries, where a high added value is created and the need for bringing into the production cycle results of activities from other sectors is on the top notch of interest (the index of gross added value is the greatest in the trade sector - $16.7 \%$, while in the processing industry it is $12.7 \%$ ), should be the engine of development for the Ukrainian economy after a crisis period. Many scientists and practitioners note that the raw material orientation of export activity must be changed to a production of high-quality, knowledge-intensive and labour-intensive competitive products.

World's leading countries focus exactly on this principle, and that's why a share of processing industry in a structure of GDP in China and South Korea is over $30 \%$, in Germany and Poland about $20 \%$, and in Ukraine - only $14 \%$.

Products from processing industry should have high competitive advantages in order to provide proper living standards in the country and make it possible to sell and promote them abroad. The specific feature of these industries is that they unite other industries of economy, thus investing into their development. 
For example, production of any product in this industry requires a presence of such components as: raw materials of a proper quality at the lowest price, and these can be results from agriculture sphere, extractive industry, etc.; creation of new workplaces and presence of skilled employees, that stimulates education development and permanent further training (in Ukraine only $8 \%$ (or 1,4 million persons) of workers of the total number of population are engaged in processing industry, in Czech Republic - 26\%, in Slovakia - $23 \%$, in Poland and Germany - $19 \%$ in South Korea - around 17\%); modern production technologies (engineering products, development of science and applied research); attraction of foreign direct investments (their share in this industry is $26 \%$ of the total volume of investments to an economy in Ukraine; for comparison: in Poland this index is 59 \%, in South Korea - $45 \%$ ); and availability of a developed market infrastructure for selling manufactured goods.

The whole complex of all mentioned factors have influenced on a fact that a share of export of processing industry commodities in a structure of export is high enough in developed countries; in particular, in China it is almost $94 \%$, in Turkey - 78 \%, and in Ukraine - only 59 \% [1].

\section{Discussion}

The problem of food safety, which is the result of development of the internal market of the country, is at focus of researches among many Ukrainian scientists, namely V. Geiets, L. Deineko, T. Ostashko, O. Shubravska etc. At the same time, international organizations constantly monitor condition of agricultural and food sector in different countries of the world. Modern tendencies of processing industry are also in the field of vision of national associations of businessmen, who try to notice negative economic trends in advance and to bend every to their improvement.

The aim of an article is to exposure a condition and basic trends of development of the meatprocessing industry in Ukraine, finding out problems in this sphere and preparing recommendations for developing individual directions for their minimization or overcoming.

\section{Research results}

We may agree that processing industry should be the key element in a process of restructuring of Ukraine's economy. Production of meat and meat products is an extraordinarily perspective direction due to historical development of economy of our country, its successful geographical location and internal potential. Thus, researchers from the Institute for Economics and Forecasting note that every additionally invested hryvna in food production industry gives $2.3 \mathrm{UAH}$ of growth in an output of this type of products, and also promotes an increase of labour payment on $0.35 \mathrm{UAH}$ [2]. Higher value of multiplicative effect could be noticed only in the coke and nuclear industry.

While analysing the basic indexes of development of meat-processing industry in Ukraine, lets notice that a number of actually working companies decreased in 2010-2012, however this tendency has changed in 2013, and only 882 economic units function in the industry at present (Fig. 1). A permanent growth of the number of workers occupied in the industry from 50.1 thousand of persons in 2010 to 62.3 thousand of persons in 2013 is also noticeable. It testifies to extensive expansion of operating production. A positive trend is an added value of index of industrial products (minimum index $103.9 \%$ in 2012, maximal value $110.5 \%$ in 2013), although in other branches of processing industry (even in the sector of food production) occurs a reduction of the actual volume of output (in particular, in the production of drinks, bread and baked goods) [3]. 


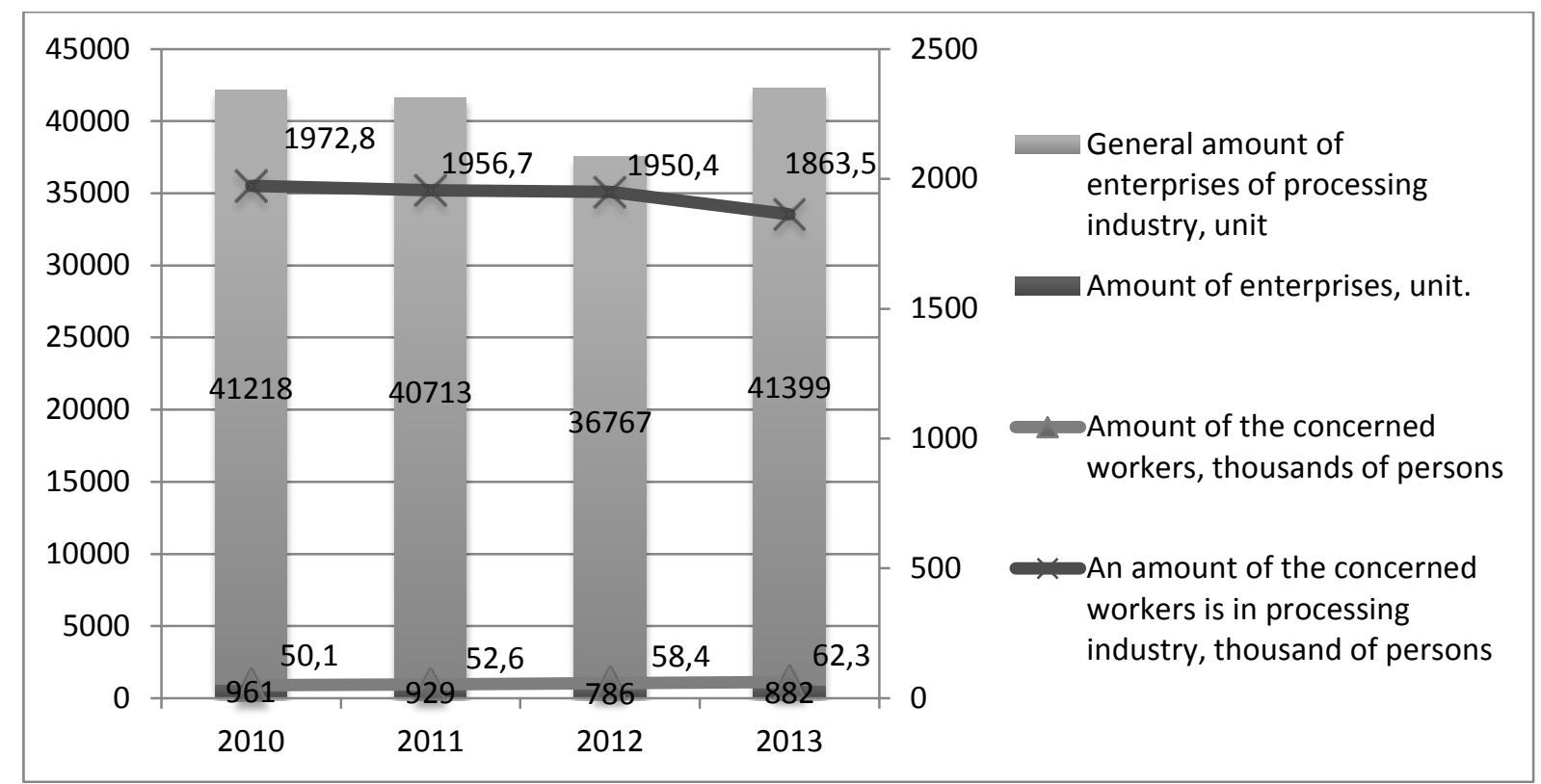

Figure 1. Position of the meat-processing industry (manufacturing of meat and meat products) in industrial structure of Ukraine in 2010-2013

Prepared according to [4]

Besides the total volume of capital investments in the processing industry grew from $30,578,8$ billion USD in 2010 to $46,240.0$ billion in 2013, but already in 2014 this volume decreased to $41.040,5$ billion USD (degree of depreciation in the processing industry was $50.1 \%$ in 2013). However, Poland's experience shows that technical modernization of one meat-processing plant needs about 2 million euro (amount of these investments was directed from the state budget) [5]. But for Ukrainian modern realities such volume of investment is impossible, and that fact actualizes the question of involvement of cheaper foreign investment.

The condition of supply of raw materials to processing companies, and a processed food and meat to population should also be taken into account. According to the research conducted by the Economist Intelligence Unit (part of the group of companies The Economist Group, UK), together with the Du Pont Company (USA), Ukraine took the 52nd place in the Global Food Security Index [6]. This indicator takes into account data on financial and physical accessibility of food and its quality and safety. International experts have determined that an indicator of food security is one of the most stable factors for the Ukrainian economy (namely the conditions for its creation and low degree losses of food).

The fact that the level of self-sufficiency in meat and meat products in Ukraine increased from $88.9 \%$ in 2011 to $93.4 \%$ in 2013 is also positive, but even this amount is insufficient, as well as the volume of farmed and imported potatoes, fruits, berries and grapes (Fig. 2). Population and producers are fully provided with other product groups, in particular with milk and milk products (though the level fell from $104.6 \%$ in 2011 to $101.6 \%$ in 2013), vegetables and melons food, eggs and grain (level of self-sufficiency increased from $161.0 \%$ in 2011 to $221.0 \%$ in 2013). 


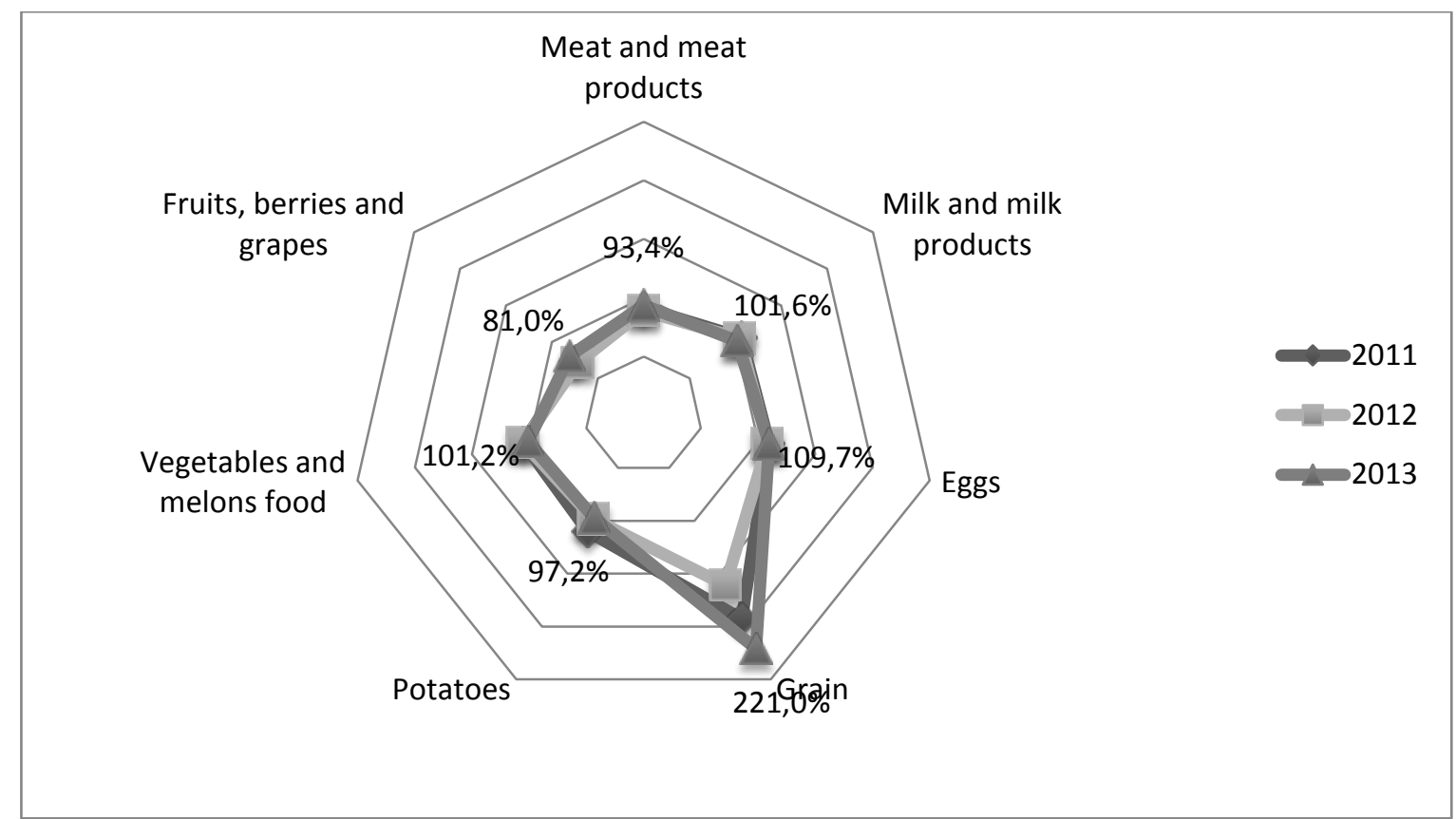

Figure 2. The level of self-sufficiency of major types of food in 2011-2013

Prepared according to [7-9]

However, the level of provision of population and manufacturers with the major types of food for almost all groups decreased during 2011-2013 (except corn), it requires the intervention of public authorities and assistance in a growth of cultivation or production at the problematic areas. Because keeping this trend of economic development strategy in the country can lead to a food crisis.

Fig. 3 shows the dynamic series of the production of various types of meat and sausage products in 2014 and early 2015 in Ukraine. A meat of poultry takes the largest share in a structure of manufacturing. During 2014 Ukraine imported about another 3.7 thousand tones [10]. A meat of cattle and pork occupy a small share in the structure of manufacturing, to compare: the manufacture of sausages is larger in physical volume. But researchers in this sphere note that the development of domestic livestock is in the doldrums [11].

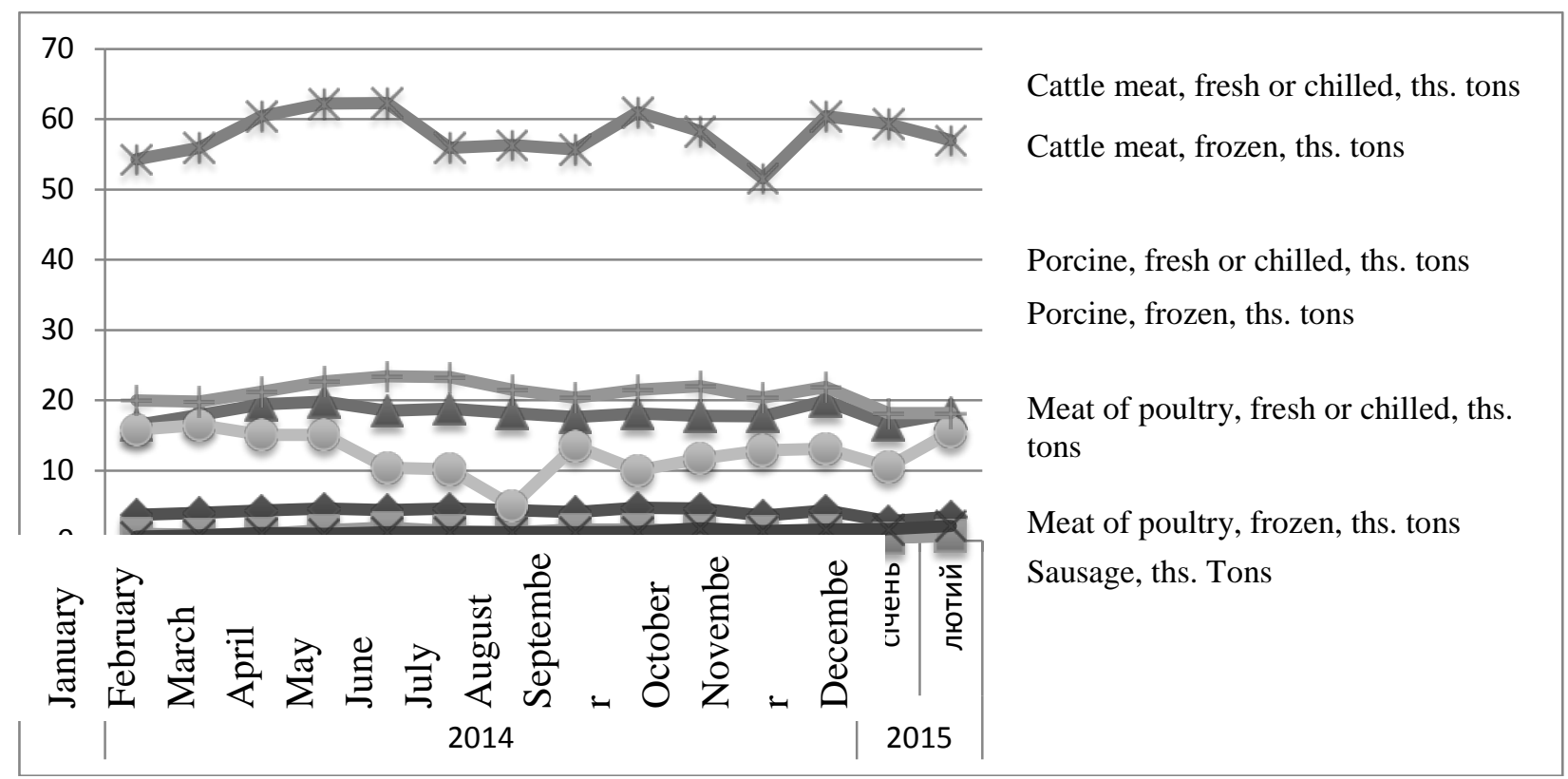

Figure 3. Manufacturing dynamics of the main types of meat

Prepared according to [10] and sausage products in 2014-early 2015 
For comparison, the Food and Agriculture Organization (FAO) estimated that in 2013 three largest world meat producers of produced together more than 100 million tons of products, namely: China - 62.47 million tons, the USA - 38.5 million tons, and Brazil - 18.0 million tons [11].

For further analysis of the state and development of the meat-processing industry, we offer to explore the dynamics of export-import operations in recent years (Fig. 4).

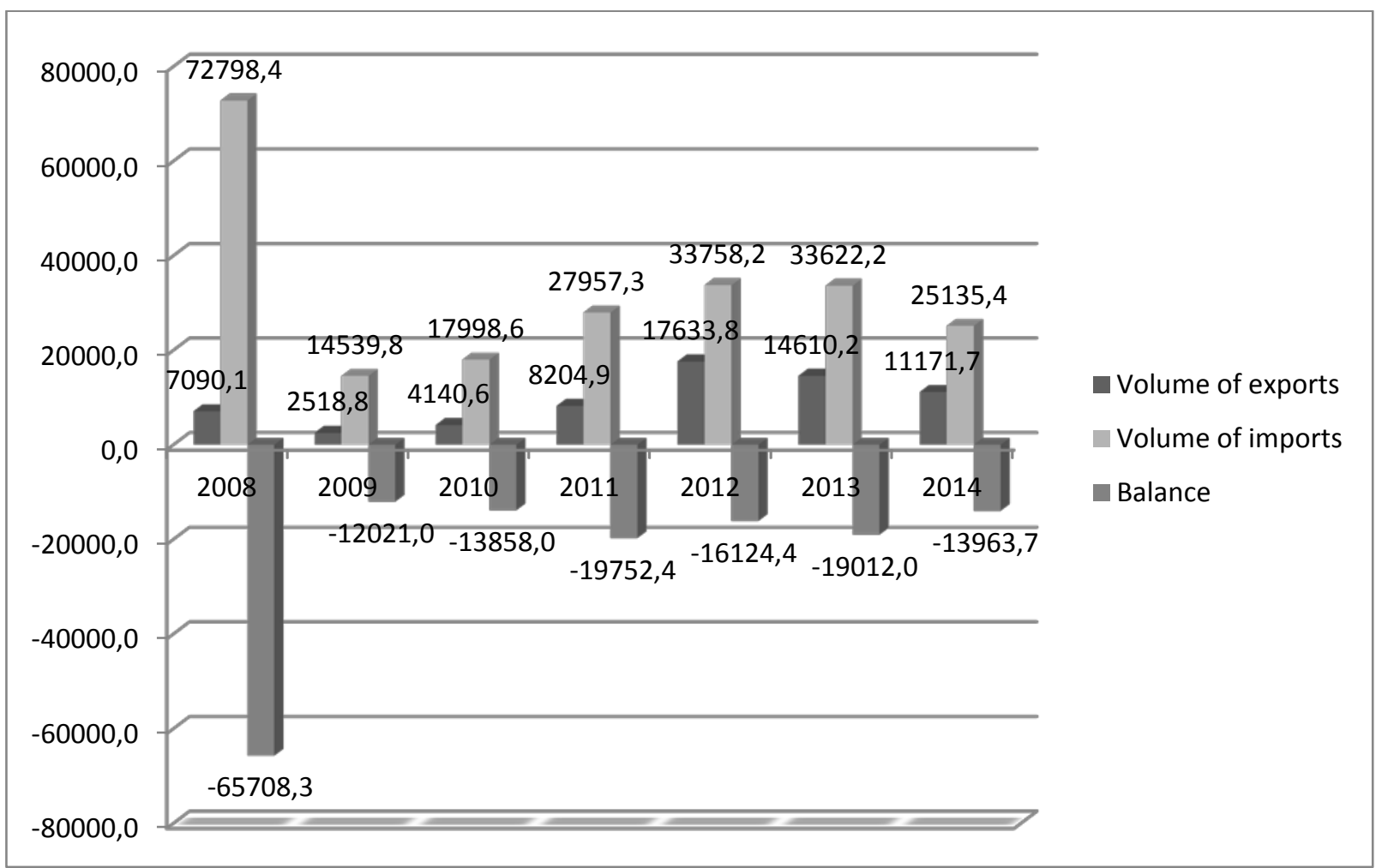

Figure 4. Dynamics of trade balance of sausages and similar prepared or preserved meat, in thousand USD

Prepared according to [10]

A tendency towards growth of export and import of meat products in Ukraine traced since 2009, but already their volume starts to decrease from 2013 and the volume of exports was 11,171.7 thousand USD and imports - 25,135.4 thousand USD in the results of 2014. The highest value of import operations was recorded in 2008 - at the level of 46,928.8 thousand USD, and exports in 2012 (in volume of 17,633.8 thousand USD).

It should be noted that during the study period there is a negative trade balance, which was the largest in 2008 (amounted to 65,708.3 thousand USD), then decreased to its lowest value in 2009 (12,021.0 thousand USD). However, the general trend in the dynamics of export / import of meat is not evident.

Reduction of the negative value in the balance of foreign trade activities in 2014 cannot be considered a positive indicator because it was a result of the simultaneous decrease in exports and imports.

The largest share in the structure of exports of meat products in 2014 belongs to sausages and similar meat products amounted to (3,727.2 thousand USD or 33.36 \%) and finished or canned products from domestic chickens (3,116 thousand USD or $27.89 \%$ ) (Fig. 5). A significant share in a general structure belongs to meat mixtures (2,576.9 thousand USD or 23.07\%) and finished or canned products of cattle (1,304.2 thousand USD or $11.67 \%)$.

As for the dynamics of exports, it should be noted that the volume of export of sausages and similar products grew in the period from 2009 to 2013, but in 2014 this value decreased by $38.9 \%$ (or 2,372.4 thousand USD). The next size group in the structure of exports (finished or canned 
products from domestic chickens) tends to increase from 2009 and 2014 reaches its maximum value $(9,323.07$ thousand USD).

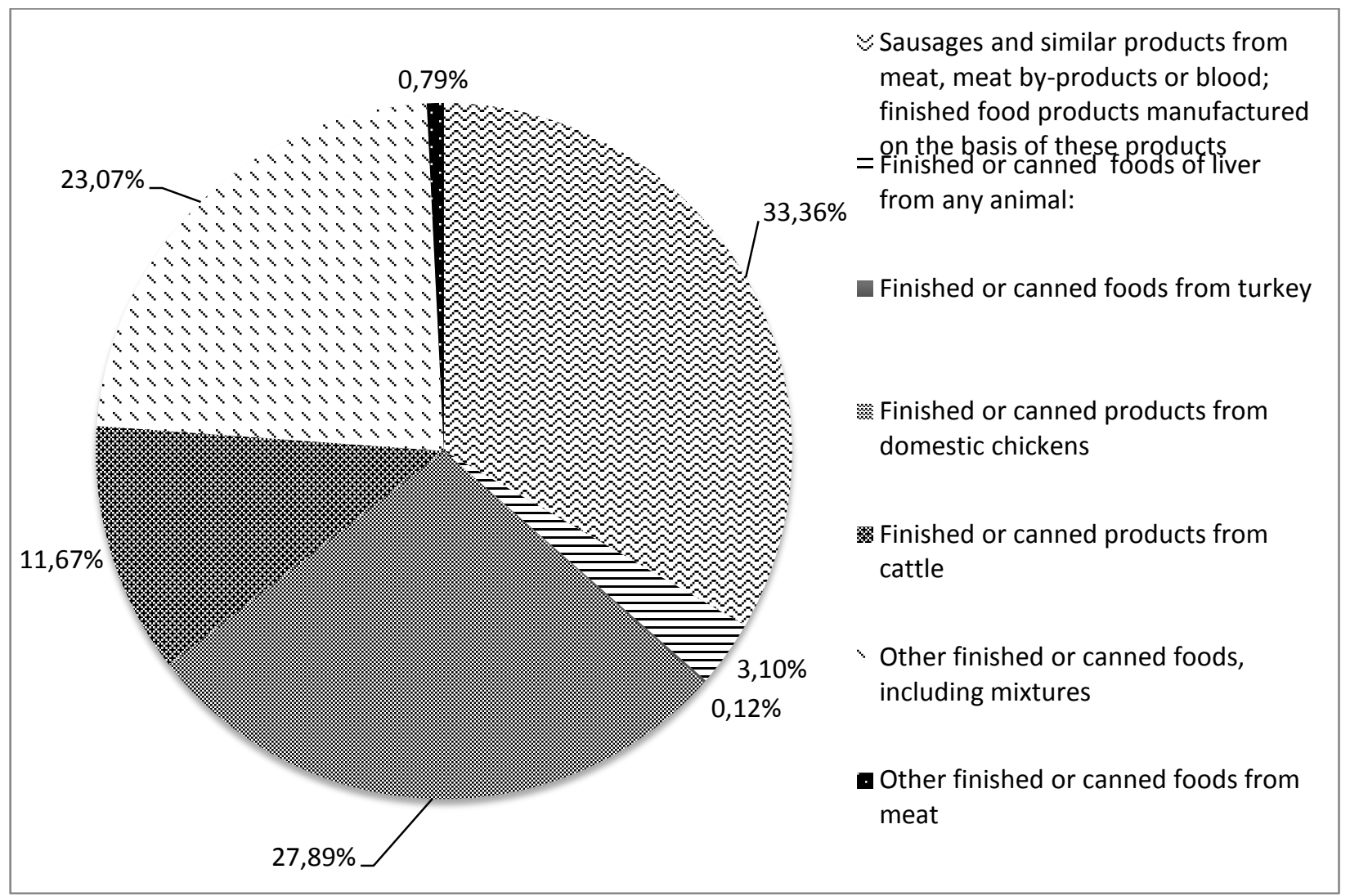

Figure 5. The structure of exports of finished products and edible meat

Prepared according to [10] by-products in 2014, in thousand USD

Let us note that this structure of exports differs by prevalence of finished products with high content of meat and by-products. However, the list of products of meat and derivative products in the structure of import operations has a slightly different composition (Fig. 6).

The largest share is reserved by finished or canned products of domestic chicken $(7,872.2$ thousand USD or 38.5\%) and sausages and similar products of meat (4,665.5 thousand USD or $22.8 \%$ ). Ham products (2,201.2 thousand USD or $10.8 \%$ ) and homogenized meat products are also imported and then sold in retail as infant food or diet food (totaling 1,185 thousand dollars USA or $5.8 \%)$. 


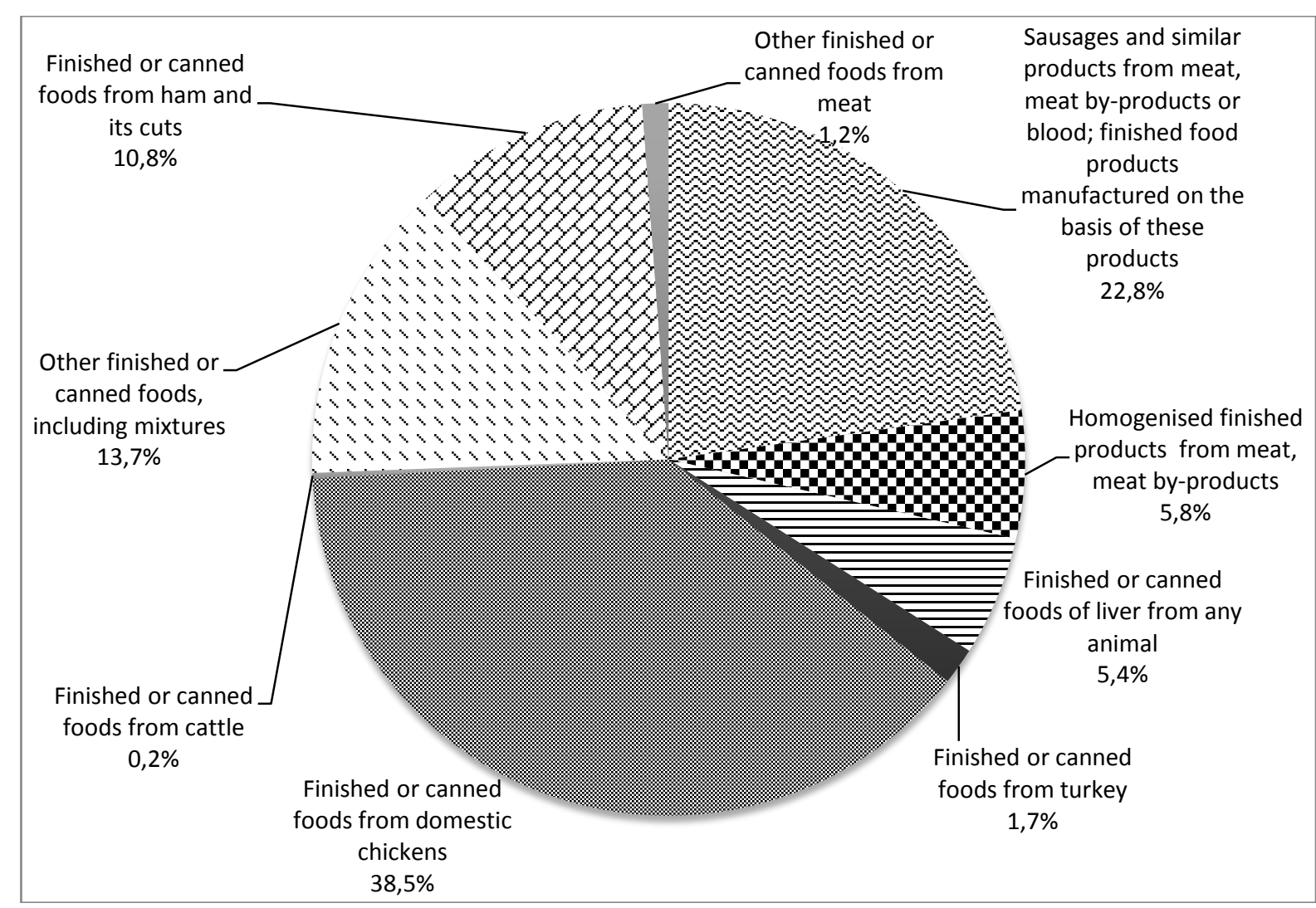

Figure 6. The structure of imports of finished products of meat

Prepared according to [10]

and edible by-products in 2014, in \%

It should be emphasized that the largest volume of import operations for finished meat products was recorded in 2008 (46,681.4 thousand USD), but after the financial crisis the volume of import of products not yet reached the pre-crisis level in any of the categories (except ham products).

It should be noted that the structure of imports has changed over the period of study: while in 2008 the largest share was occupied by sausages and similar products (44.6\% and in 2014 $22.8 \%$ ), in 2014 finished or canned domestic chicken products dominated in the import structure (38.5\% and in 2008 accounted for $20 \%$ ).

The interesting fact is that the value of exported sausages and similar products is on average USD 4 per $1 \mathrm{~kg}$ of product, while the average price per $1 \mathrm{~kg}$ of imported products is USD 6.32 . This means that domestic consumers have to pay more for this group of goods as they buy foreign meat products. At the same time this cost difference for finished or canned domestic chicken products is not so significant and amounts to USD 0.24 per $1 \mathrm{~kg}$ of product.

Thus, added positive balance of trade of finished meat products is observed only in cattle product categories, which indicates the negative development factor of the industry.

Regarding the geographical structure export and import operations, the overwhelming share of Ukrainian goods is exported to CIS countries (namely $71.4 \%$ of total exports), where the largest importer of Ukrainian products and edible by-products in 2014 was the Russian Federation (amounting to USD 5,539.56 thousand). Accordingly, 28.6\% of exports of finished meat products (amounting to USD 3,191.02 thousand USD) is sent to other countries of the world: to Europe $22.8 \%$ of total exports (or USD 2,549.53 thousand in money equivalent), where the most active partner of Ukraine are the Netherlands (the cost of purchased goods was USD 1,457.3 thousand); to the Asian region - $5.3 \%$ (or USD 589.62 ), with the largest share of Ukrainian products sold to Georgia (USD 321.87 thousand ); the share of products exported to America and Australia and Oceania is low (0.35\% and $0.03 \%$, accordingly) (Table 1$)$. 
Table 1: Geographic structure of export and import of meat products and edible by-products in 2008 and 2014

\begin{tabular}{|l|l|c|c|c|c|}
\hline \multirow{2}{*}{ № } & \multicolumn{2}{|c|}{ Region } & \multicolumn{3}{c|}{ Years } \\
\cline { 3 - 6 } & & \multicolumn{2}{|c|}{2008} & \multicolumn{2}{c|}{2014} \\
\cline { 3 - 6 } & & $\begin{array}{c}\text { Volume of } \\
\text { exports, th. } \\
\text { USD }\end{array}$ & $\begin{array}{c}\text { Volume of } \\
\text { imports, th. USD }\end{array}$ & $\begin{array}{c}\text { Volume of } \\
\text { exports, th. } \\
\text { USD }\end{array}$ & $\begin{array}{c}\text { Volume of } \\
\text { imports, th. } \\
\text { USD }\end{array}$ \\
\hline 1 & Total volume & $7,090.1$ & $72,798.4$ & $11,171.7$ & $25,135.4$ \\
\hline 2 & Countries of CIS & $5,716.0$ & $35,847.6$ & $7,980.7$ & $4,944.4$ \\
\hline 3 & $\begin{array}{l}\text { Other countries, } \\
\text { including: }\end{array}$ & $1,374.1$ & $36,950.8$ & $3,191.02$ & $20,191.0$ \\
\cline { 2 - 6 } & Europe & 481.9 & $32,963.3$ & $2,549.5$ & $20,124.8$ \\
\cline { 2 - 6 } & Asia & 259.0 & 0 & 589.6 & 1.8 \\
\cline { 2 - 6 } & Africa & 16.1 & 0 & 521.6 & 0 \\
\cline { 2 - 6 } & America & 287.0 & $3,987.5$ & 38.9 & 63.5 \\
\cline { 2 - 6 } & Australia and Oceania & 0.5 & 0 & 3.3 & 0 \\
\hline Others & 329.5 & 0 & 8.5 & 0.9 \\
\hline
\end{tabular}

Prepared according to [10]

As was already noted, the volume of imports of finished meat products and edible byproducts amounted to USD 25,135.4 thousand in 2014. However the geographical structure of import operations for the year significantly differed from exports. About $20 \%$ of products were imported from the CIS countries, with most goods imported from Belarus (amounting to USD 177.1 thousand). For comparison, in 2008 the structure of imported products was almost completely divided between the CIS and a large group of other countries. In 2014 the overwhelming share of imported goods has been imported from Europe - 80.1\%, in particular from Germany - the amount of USD 5,672.3 thousand. No meat products were imported from Africa and Australia.

\section{Conclusion}

So, the analysis of the current state of the meat-processing industry and analysis of scientific publications on this area reveals the following problems:

- sharp reduction of effective demand (due to the reduction of real wages, rising inflation, growth in the total level of prices, devaluation of national currency);

- significant dependence of the domestic market on fluctuations of the world market where OECD (Organization for Economic Co-operation and Development) and FAO (Food and Agriculture Organization) analysts define the main threats to the following factors: increase in the scope (share) of manufacture in some countries, rising prices for production resources (especially energy), fluctuations in prices for basic agricultural products on the world market, trade restrictions etc.;

- significant predominance of meat products imports over exports along with a high level of self-sufficiency of raw materials;

- although export orientation has become more diversified over the period of study, the prevalence of the share of products directed to the CIS countries demonstrates deformation of the structure. Some experts note the attractiveness of the Asian region (in capacity and demand level) [14];

- low level of tariff protection of Ukrainian producers of meat and finished meat products (especially after joining the WTO) from imported substitutes [15];

- inability to apply non-tariff methods of protection to the domestic producers (setting minimum import prices, bans on imports and import quotas) due to its commitments in the international arena;

- lack of certificates of quality and food safety, control system for these indicators, quality management according to international standards in most Ukrainian meat-processing enterprises; 
- lack of a balanced infrastructure of the internal market, as regards both the financial sector and logistic components.

The study allows us to offer the following steps to overcome the problems that have developed in the meat processing sector but can be solved only with the support of the state. These steps include:

1) stimulation of meat production (in particular, cattle and pork) and edible by-products by domestic food enterprises, which requires qualitative changes in the livestock sector;

2) supporting the development of food engineering to ensure manufacturing of new technological equipment for production of quality products as well as its storage, pre-packing, and packing, that will increase the competitive opportunities of finished meat products;

3) differentiation of the structure of production and exports, focus on products with the best quality characteristics, which generally have higher added value;

4) gradual implementation of the strategy of import substitution of certain types of meat products, with priority given to quality goods with a relatively low cost;

5) active state export policy, which should be focused on the expansion of markets and creation of incentives increasing exports (and production) of better quality products;

6) investment in international marketing and creation of a reliable brand of the country in the first place;

7) restriction of import of poor quality products used to reduce the cost and usefulness of finished meat products;

8) support for standardization and implementation of environmental standards in the manufacturing process, facilitating certification procedures;

9) support and provision of effective demand in the domestic market, which will provide positive financial results for producers and facilitate investment in intensive industry development.

In circumstances of drawing near to the European integration, the state policy should focus on the protection of national interests, especially in the long term. In addition to macroeconomic trends of the industry, a competitive environment where companies of meat processing industry operate should also be investigated. The main obstacles in entering the new markets should be discovered and described. This is an interesting area for further research.

\section{References:}

1. Symposium of Anticrisis Council of Ukrainian League of Industrialists and Enterpreuners (April, 3rd, 2015), Kyiv, Ukraine.

2. Dejneko, L.V., Ostashko T.O., Tochy` lin V.O. and al (2013), Problemy, napryamy ta chynnyky spryyannya rozvytku vnutrishnogo rynku Ukrayiny (realnyj sektor ekonomiky): monografija [Problems, strategies and factors for development of Ukrainian domestic market (real sector of economy): monograph], Institute for economics and forecasting, National Academy of Sciencies of Ukraine, Kyiv, Ukraine, 292 p.

3. The official site of State Statistics Service of Ukraine (2014), "Indexis of industrial production by types of activities in 2013-2014", available at: https://ukrstat.org/uk/ operativ/ operativ2007/pr/prm_ric/prm_ric_u/ipv2013_u_bez.html

4. Kuznyeczov, M. S. (2014), Diyal 'nist 'subyektiv gospodaryuvannya 2013: Statyst. zb. [Activity of business entities 2013: statistical publication], State Statistics Service of Ukraine, Kyiv, Ukraine, $447 \mathrm{p}$.

5. Mudrak, R.P. (2014), Export of Ukrainian commodity goods: state, tendencies and reasons, Economy of Ukraine, Kyiv, Ukraine, \#5 (630), pp. 70-79

6. Global Food Security Index (2015), Electronic resources, available at: http:// foodsecurityindex.eiu.com/ Country/ Details\#Ukraine

7. Vlasenko, N. S. (2014), Balansy ta spozhyvannya osnovnyx produktiv xarchuvannya naselennyam Ukrayiny za 2013 r. : Staty`st. zb. [Balances and consumption of main food categories by Ukrainian population in 2013: statistical publication], State Statistics Service of Ukraine, Kyiv, Ukraine, $54 \mathrm{p}$.

8. Vlasenko, N. S. (2013), Balansy ta spozhyvannya osnovnyx produktiv xarchuvannya naselennyam Ukrayiny za 2012 r. : Staty`st. zb. [Balances and consumption of main food categories 
by Ukrainian population in 2012: statistical publication], State Statistics Service of Ukraine, Kyiv, Ukraine, $56 \mathrm{p}$.

9. Vlasenko, N. S. (2012), Balansy ta spozhyvannya osnovnyx produktiv xarchuvannya naselennyam Ukrayiny za 2011 r. : Staty`st. zb. [Balances and consumption of main food categories by Ukrainian population in 2011: statistical publication], State Statistics Service of Ukraine, Kyiv, Ukraine, $54 \mathrm{p}$.

10. The official site of State Statistics Service of Ukraine (2015), "Export/import of goods by countries in J anuary-December 2014 (table 45.1)", available at: https:// ukrstat.org/ uk / operativ / operativ2014/ zd/e iovt/arh iovt2014.htm

11. Ostashko, T. O., Voloshhenko, L. Yu. and Lyenivova, G. V. (2010), Vnutrishnij agroprodovol ` chy j ry nok Ukrayiny` v umovax SOT [Domestic agricultural market of Ukraine in conditions of WTO], Institute for economics and forecasting, National Academy of Sciencies of Ukraine, Kyiv, Ukraine, $292 \mathrm{p}$.

12. The official site of State Statistics Service of Ukraine (2015), "Production of main industrial goods types by monthes", available at: https://ukrstat.org/uk/operativ / operativ2013/pr/ ovp/ ovp_u/ovp2013.html

13. Statistic division of Food and Agriculture Organization of the United Nations (2015), "Production of commodity in selected countries", available at: http://faostat3.fao. org/ browse/Q/QL/ E

14. Shubravs'ka, O. V. (2014), "Agro-industrial development of Ukraine under global challenges", Economy of APC, Ukraine, 7, pp. 53-58

15. Krysanov, D.F. and Vodyanka, L.D. (2013), "Innovative potential of food-processing companies: evaluation and implementation", Economics and forecasting, Kyiv, Ukraine, \#2 (AprilJune), pp. 84-105.

УДК 338.12

\section{Развитие мясоперерабатывающей отрасли в Украине: тенденции, проблемы и пути их решения}

\section{Екатерина Николаевна Власова}

Киевский национальный университет имени Тараса Шевченка, Украина Аспирант

E-mail: nadtochii@ukr.net

Аннотация. Эта статья описывает текущее состояние мясоперерабатывающих предприятий в Украине, используя для этого такие показатели: количество работников, задействованных в данной отрасли и во всей перерабатывающей промышленности, количество действующих компаний, индекс производства и др. Автор предлагает изучить самообеспеченность основными продуктами как результат деятельности мясоперерабатывающих предприятий на внутреннем рынке и динамику торгового баланса по различным видам мяса - как результат на международном рынке. Результаты анализа подчеркивают необходимость обратить внимание на основные проблемы в отрасли: отрицательное сальдо торгового баланса, недостаточнсть производства в стратегических сферах, высокие цены на импортные товары по сравнению с более низкими на аналогичный национальный продукт. Структура экспорта была сравнена с импортом, чтобы определить наиболее несбалансированные категории на внутреннем рынке. Анализ географической структуры экспортно-импортных операций показал, что диспропорция может привести к необратимой отрицательной трансформации мясоперерабатывающей промышленности. Также предлагается ряд стратегий для преодоления этих проблем.

Ключевые слова: барьеры входа, мясоперерабатывающая отрасль, инвестиции, самообеспеченость, торговый баланс, стратегии преодоления проблем. 